\title{
Corynebacterium urealyticum
}

Corynebacterium urealyticum pertenece al Dominio Bacteria, grupo Bacterias Gram Positivo con alto contenido G+C, Orden Actinomycetales. Familia Corynebacteriaceae, Género Corynebacterium. Previamente denominado Corynebacterium D2, esta especie corresponde a bacilos grampositivos, aerobios estrictos. $\mathrm{Su}$ pared celular contiene ácidos micólicos de 22-36 átomos de carbono constituyendo el grupo denominado C- M- N (Corynebacterim, Mycobacterium, Nocardia). Corynebacterium urealyticum no es ácido alcohol resistente y su crecimiento es lento. Es un aerobio estricto no esporulado, que forma parte de microbiota comensal de la piel y mucosas. Bimet y cols estimaron que $12 \%$ de los individuos sanos y $30 \%$ de pacientes hospitalizados pueden ser portadores de este microorganismo. Se le ha aislado del tracto urinario como agente etiológico de cistitis y pielonefritis aunque con frecuencia baja; se ha reportado entre 0,025 y $0,32 \%$. Sin embargo, en pacientes con transplante renal (TR) puede ser el principal causante de cistitis incrustante $(\mathrm{CI})$ y pielitis incrustante (PI). Factores que favorece las incrustaciones cálcicas son: la presencia de bacterias específicas asociadas a orina alcalina; un contexto clínico de inmunosupresión y tratamiento antimicrobiano prolongado; manipulaciones urológicas, responsables de la contaminación del tracto urinario y lesión pre-existente del urotelio ${ }^{1}$. Otras infecciones asociadas con este especie bacteriana son endocarditis, bacteriemia y neumonía

Diagnóstico de laboratorio. Las muestras de orina que presentan ciertas características sugieren la presencia de C. urealyticum: piuriahematuria; $\mathrm{pH}$ alcalino; presencia de cristales de estruvita (fosfato amónico magnésico). Aunque no siempre se observan estos tres signos, la integridad de los leucocitos se ve muy afectada por la alcalinidad del medio. En otro tipo de infecciones, la presencia de leucocitos, polimorfonucleares y organismos diftermorfos pueden sugerir una infección. Cuando los cultivos son negativos a las $24 \mathrm{~h}$, se sugiere prolongar la incubación, especialmente si hay información clínica $u$ otros datos de laboratorio que apoyen la existencia de una infección bacteriana.

Identificación. Corynebacterium urealyticum. Crece a $37^{\circ} \mathrm{C}$ en agar sangre de cordero al 5\%. A las $24 \mathrm{~h}$ de incubación, las colonias son muy pequeñas, menores de $2 \mathrm{~mm}$ de diámetro; a las 48-72 h alcanzan un tamaño entre 2 y $4 \mathrm{~mm}$ de diámetro y sus características macroscópicas son: colonias redondas, lisas y blanquecinas (Figura 1a). Crece bien en agar chocolate, se han desarrollado medios selectivos para aislar esta bacteria; estudios previos indican que no está recomendado su uso de rutina $^{2}$. La bacteria es lipofílica, al Gram se ven bacilos grampositivos irregulares, lados curvos y no paralelos, frecuentemente agrupados (a veces se pueden observar cocobacilos con una morfología más cocoide que bacilar). Es catalasa + , nitratasa - y ureasa + , esta última prueba es muy útil ya que se torna positiva en pocos minutos (Figura 1b). Puede ser diferenciado de $C$. jeikeium por su incapacidad de oxidar carbohidratos y la ureasa.

Susceptibilidad antimicrobiana. Corynebacterium urealyticum es usualmente resistente a los $\beta$-lactámicos y aminoglucósidos, susceptible a vancomicina y de susceptibilidad variable a quinolonas, eritromicina, rifampicina, y tetracyclina ${ }^{3}$.

\section{Referencias}

1.- Vázquez V, Morales MD, Serrano C, Reus $\mathrm{M}$, Llorente S y García J. Corynebacterium urealyticum in renal trasplantation. CT and

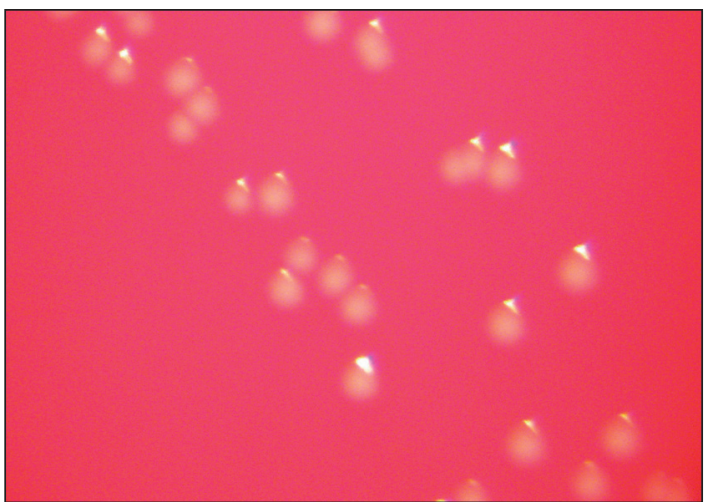

Figura 1a. Colonias de C. urealyticum 48 horas en agar sangre. sonography imaging characteristics of encrusted cistitis and pielitis. Nefrología 2004; 24 (3): 288-93.

2.- Soriano F, Zapardiel J, Ponte C. Use of selective media for isolating Corynebacterium urealyticum from urine specimens. J Clin Microbiol 1994; 32 (10): 2630-1.

3.- Funke G, Von Graevenitz A, Clarridge III JE, Bernard KA. Clinical microbiology of coryneform bacteria. Clin Microbiol Rev 1997; 10 (1): 125-59.

M. Teresa Ulloa F. Programa de Microbiología- Micología. Instituto de Ciencias Biomédicas (ICBM) Facultad de Medicina, Universidad de Chile

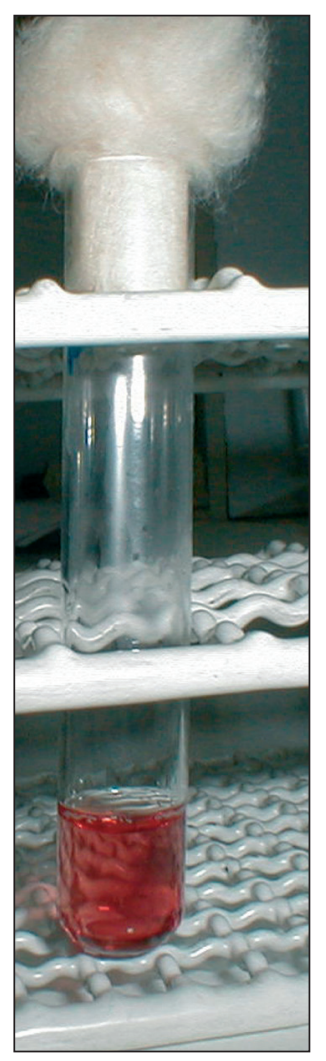

Figura 1b. Cepa de C. urealyticum ureasa positivo. Lab. MTUlloa 2008. 